\title{
Short-term shoreline evolution trend assessment: A case study in Glefe, Ghana
}

\author{
Authors: \\ Kwadwo Y. Amoani ${ }^{1}$ \\ Kwasi Appeaning-Addo ${ }^{1}$ \\ Wahab S.Laryea ${ }^{1}$ \\ Affiliations: \\ ${ }^{1}$ Department of \\ Oceanography and Fisheries, \\ University of Ghana, Accra, \\ Ghana \\ Correspondence to: \\ Kwadwo Amoani \\ Email: \\ amonai16@yahoo.com \\ Postal address: \\ PO Box 63, Mamfe-Akuapem, \\ Ghana \\ Keywords: \\ RTK-GPS; Coastal \\ Management; Coastal \\ Erosion; Accra-Ghana \\ Dates: \\ Received: Nov. 2011 \\ Accepted: 09 May 2012 \\ Published: 19 July 2012 \\ How to cite this article: \\ Amoani, K.Y., Appeaning- \\ Addo, K., \& Laryea, W.S. \\ 2012, 'Short-term shoreline \\ evolution trend assessment: \\ A case study in Glefe, Ghana', \\ Jàmbá: Journal of Disaster \\ Risk Studies 4(1), Art. \#45, \\ 7 pages. http://dx.doi. \\ org/10.4102/jamba.v4i1.45
}

(C) 2012. The Authors. Licensee: AOSIS OpenJournals. This work is licensed under the Creative Commons Attribution License.
The growing economic, social and ecological importance of coastal areas in Ghana has increased the challenges associated with sustainably managing the coastal resources. The coastal areas have become more prone and vulnerable to natural and human-made hazards such as coastal erosion. Shoreline retreat is recognised as a burgeoning threat because of global climate change and other anthropogenic activities that alter the natural processes sustaining beaches and coasts. This article describes an application of Real-time Kinematic-Global Positioning System (RTK-GPS) technology and digitising of shorelines from orthophotos to detect and analyse the spatial changes as well as quantify the result of shoreline change at Glefe, a suburb of Accra in Ghana. Shoreline positions from a 2005 orthophoto and a 2011 RTK-GPS survey were overlaid in MATLAB (Matrix Laboratory) and the average rate of change determined using the endpoint rate (EPR) method. The shoreline change rate determined for Glefe between 2005 and 2011 was $1.2 \mathrm{~m} / \mathrm{a} \pm 1.3 \mathrm{~m} / \mathrm{a}$, indicating a relatively high rate of erosion. Outcomes of the case study can be used as a basis for a sustainable integrated management plan for the coastal area.

\section{Introduction}

Globally it is estimated that about $60 \%$ of the human population dwell in coastal environments (Al-Tahir \& Ali 2004). Although the coastal environment can retain some degree of natural character, increased human modification reduces the 'naturalness' (Dahm 2000). According to Armah (2005), 25\% of the estimated 22 million population of Ghana live in the four coastal regions, namely the Volta, Greater Accra, Central and Western regions, and depend on coastal resources in diverse ways.

Due to increased coastal erosion as a result of high population growth (United Nations Environment Programme 1999) and other factors such as storm events, seasonal fluctuations in wave energy and changes in sea level, coastal areas are continually changing. These changes impact significantly on the coastal environment and have a tendency to result in a disaster if not properly managed. A major effect of coastal environmental change is coastal erosion, which becomes a hazard when it threatens life and property and affects the socio-economic life of the coastal population. In Ghana coastal erosion is impacting negatively on the emerging coastal tourism industry, small-scale fishing industry and local revenue generation. Increasing human activities within the coastal zone have exacerbated the erosion problems, resulting in about 24 locations being declared hotspot zones that need urgent attention (Nail et al. 1993).

The accelerated release into the atmosphere of carbon dioxide and other greenhouse gasses has resulted in a projected global warming of about $3^{\circ} \mathrm{C}$ by the year 2030 (Davis \& Fitzgerald 2010). This increase would be enough to raise the global sea level by as much as $5 \mathrm{~m}$ in a few centuries (Davis \& Fitzgerald 2010), which is a short time in terms of human occupation of the coast. This phenomenon has the tendency to expose a significant proportion of vulnerable coastal areas to flooding and destruction of habitats for migratory birds and other endangered species. Occurring in synchrony with these continual changes is the recession of shorelines, estimated to occur on about $70 \%$ of the world's sandy beaches (Bird 2008). Added to this situation are the effects on coastal population and infrastructure of major economic and cultural importance in almost all coastal regions globally.

The location of the shoreline and changing position of this boundary through time are of elemental importance to coastal scientists, engineers and managers (Douglas \& Crowell 2000). Relief and development agencies also depend on such information to facilitate development of effective measures to prevent, mitigate or manage disasters. Both sustainable coastal management and engineering design require information about where the shoreline is, where it has been in the past, and where it is predicted to be in the future. Such information is required in the design of coastal protection (Coastal Engineering Research Centre 1984), to calibrate and verify numerical models 
(Hanson et al. 1988), to assess sea-level rise (Leatherman 2001) and develop hazard zones (Bellomo et al.) Douglas, Crowell \& Leatherman 1998, to formulate policies to regulate coastal development (National Research Council 1990), and to assist with legal property boundary definition (Morton \& Speed 1998) as well as coastal research and monitoring (Smith \& Jackson 1992).

In Ghana and most sub-Saharan countries records of the historic and predicted shoreline change are scarce (Appeaning-Addo, 2009a). This has influenced development of pragmatic policies and programmes to sustainably manage areas that are risk-prone. Studies by AppeaningAddo et al. (2008) estimated the rate of erosion in the coastal zone of Accra as $1.13 \mathrm{~m} / \mathrm{a} \pm 0.17 \mathrm{~m} / \mathrm{a}$, which is relatively high. The problems associated with the relatively high rate of erosion in Glefe demand that a localised erosion rate should be computed for Glefe and its environs.
The petrochemical industry uses a huge amount of salt in production, which demands increased salt production to support both domestic and industrial use. In view of this, efforts should be made to protect salt production units in the country, especially in view of the oil discovery in Ghana. Glefe houses one such production unit, Pambros Salt Production Limited, whose production capacity is already under intense pressure due to dependency upon it by most African countries (Oppong \& Quashie 2006). There is therefore a need to raise awareness about the imminent threat the salt production facility faces and the need for protection. This would also go a long way to support the rapidly developing oil industry, which attracts interest both locally and internationally.

This study used a more recent method of mapping the shoreline, the Real-time Kinematic Differential Global Positioning System (RTK-GPS), which is mounted on an

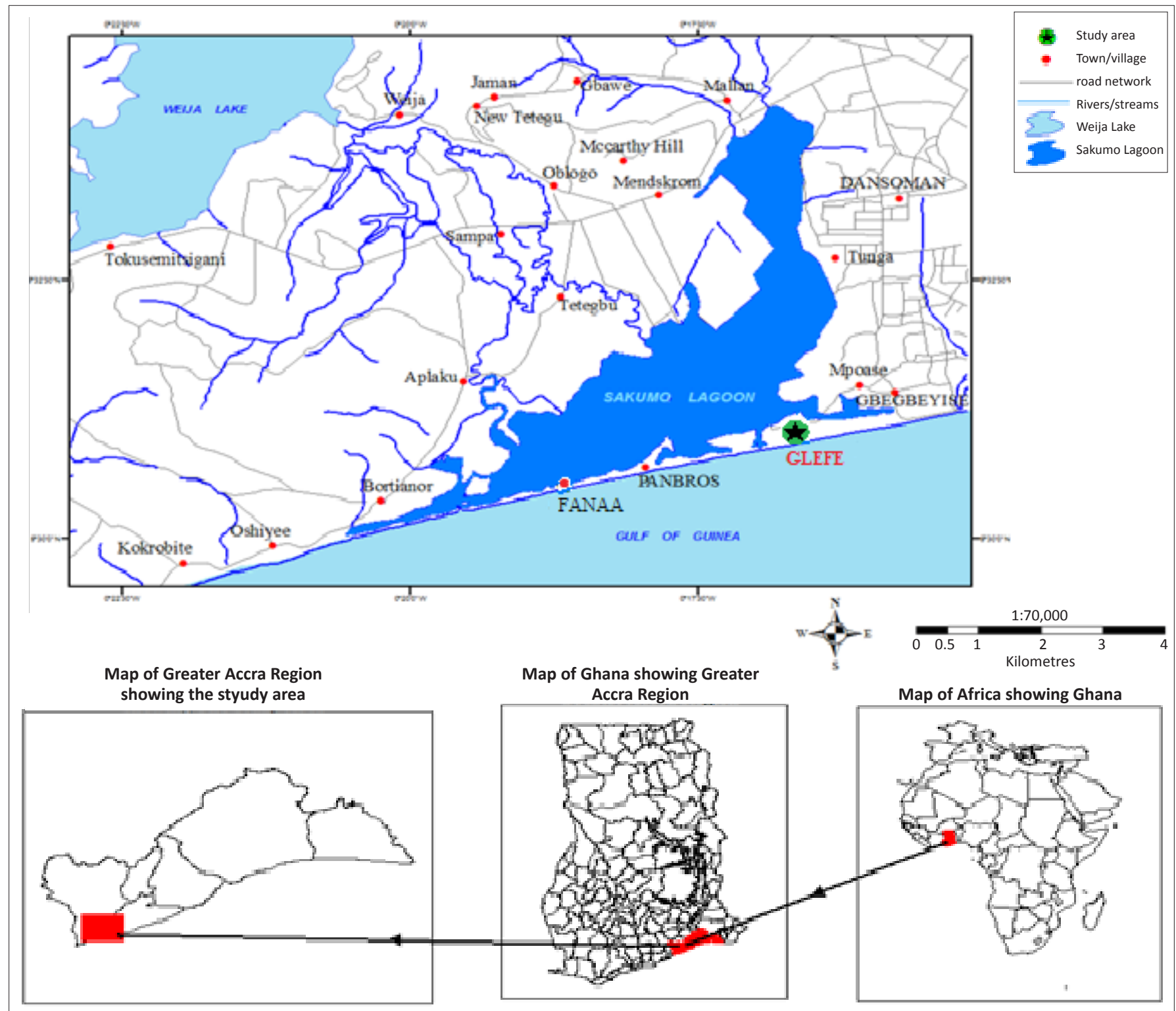

Source: Oteng-Ababio M., Owusu K. \& Appeaning-Addo, K., 2011, 'The vulnerable state of the Ghana coast: The case of Faana-Bortianor', Jàmbá: Journal of Disaster Risk Studies 3(2), 429-442. FIGURE 1: The study area (Glefe) located in the Densu wetland area. 
automobile or on a backpack and driven at a constant speed along the visibly discernible line of interest (Morton et al. 1993). This enables the changes to be detected and the rates estimated. Ground-based survey methods of mapping the shoreline position have evolved from theodolite to total station and in recent times to the Global Positioning System (GPS) (Appeaning-Addo 2009b). Mounting the GPS on an all-purpose terrain vehicle or on a backpack and driving it at a constant speed along the visible shoreline proxy facilitates faster mapping of the shoreline in real time.

According to Morton and Speed (1998), the GPS method reduces operational costs and gives a relatively accurate result. A study by Pajak and Leatherman (2002) concluded that mapped shoreline positions using the GPS method were more reliable than those extracted from aerial photographs using photogrammetric methods. In this study the locations of instantaneous shorelines at two separate times have been used to analyse shoreline change in the study area over a period of six years (2005-2011). Using the single transect method as described in Romine et al. (2009), the end-point rate (EPR) of shoreline change for the six years was calculated by overlaying the instantaneous shoreline positions from years 2005 and 2011 in a MATLAB (Matrix Laboratory) programming environment.

\section{Study area}

Glefe and its environs, a coastal suburb in Accra, Ghana (Figure 1) is experiencing relatively severe erosion. It is located at latitude $5^{\circ} 19^{\prime} 5^{\prime \prime} \mathrm{N}$ and longitude $0^{\circ} 6^{\prime} 0^{\prime \prime} \mathrm{W}$ along the Gulf of Guinea and falls within the central geomorphic region of Ghana (Appeaning-Addo et al. 2008). Similar to most parts of the Accra coast, Glefehas a relatively open coastline that enables considerably strong, unimpeded swell waves to reach the coast (Appeaning-Addo 2009b) and to break obliquely, generating long-shore currents (Ly 1980). The significant wave height for $50 \%$ of the time is about $1.4 \mathrm{~m}$, the period is $10-15$ seconds and spring high tide is about $1.26 \mathrm{~m}$ (Appeaning-Addo 2009b). The study area is low-lying, and hence has stagnant water pools in many parts. The township is situated on the barrier (sand bar) separating the sea from the Densu wetland. Although not a resort destination for holiday-makers, the area is in close proximity to major holiday destinations in the capital, namely Bojo beach resort, Bolla beach, Big Mamas and Bortianor beach resort, amongst others.

Glefe's beach is made up of a long sand bar traversing about $2 \mathrm{~km}$ of the coast, behind which is a lagoon locally known as Bugbe or Gyatakpo. Morphological differences along the beach are absent as it is made up of a long sand bar which is only partially divided into an eastern and western section by the Pambros salt production area. This salt production site is protected by boulders, hence appearing as a riprap (rocks or other materials used to armour shorelines against the impact of coastal erosion). Although erosion is evident on the entire beach, its signature is mostly seen on the eastern section, where the width of the sand bar is greatly reduced

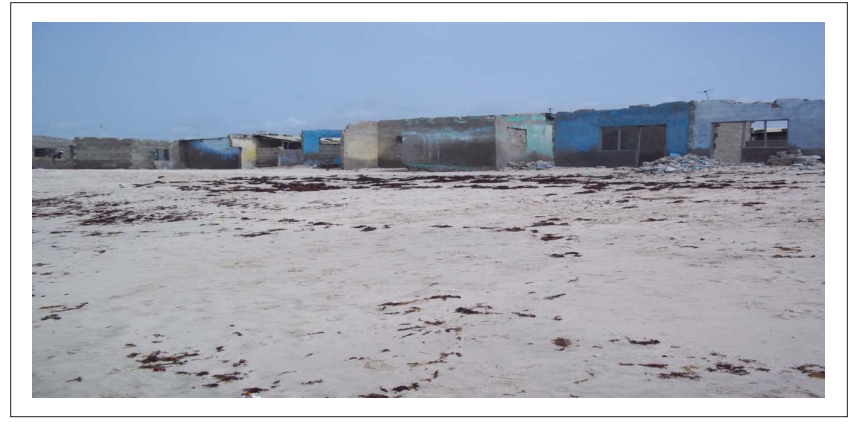

Source: Photo taken by Kwadwo Amoani, Kwasi Appeaning-Addo, Wahab Laryea

FIGURE 2: Severe erosion experienced on the eastern portion of Glefe beach.

and settlements are suffering the consequences of erosion (see Figure 2). The western section, though also experiencing erosion, has a wider sand bar (about $80 \mathrm{~m}$ wide) with its back beach heavily carpeted by grass. Behind the sandbar on this section of the beach is a stretch of mangrove species which is predominantly Avecinianitida, identifiable by the presence of salt crystals on its leaves. Also located here is wind-pruned vegetation.

Seasonally the entire stretch is affected by a huge pile of brown algae (Sargassum vulgares) being washed onshore. According to Armah et al. (2004) these are tropical species found attached to hard substrates in shallow water, and are brought to the beaches in such huge piles only when there are turbulent flows which detach them from their substrates. In spite of the absence of hard substrates at Glefe, these species are found there. This may be due to the presence of rocks in the continental shelf along this stretch. Their abundance is seasonal, in relation to upwelling and associated turbulent flows, but according to local inhabitants in recent years their occurrence has been highly unpredictable due to frequent occurrence of turbulent flow.

Observations indicate that the inhabitants of Glefe and surrounding areas depend on the beach in many ways. Some use it as a landing site and canoe dock. The main fishing methods used here are hook and line and hand-picking of clams. Major fish species caught include horse mackerel (locally known as 'Kpanla'), shrimps (locally known as 'son'), and clams. A documentary on Joy FM radio station by De-Graftin 2011 revealed the havoc that erosion is causing to the environment at Glefe. The programme reported that a significant percentage of the population have lost properties due to erosion. Increased erosion in recent times continues to threaten recreational activities and industries.

The western coast of Accra houses many sensitive installations such as offices, factories, beachfront hotels, resort getaways, major roads and features of historical and cultural significance, which are increasingly being left tottering into the sea as a result of erosion reaching epidemic levels. One of these installations includes Pambros Salt Production Limited. In view of this loss, communities and individual property owners often spend lots of money to protect their properties (Cunningham \& Cunningham 2006). However, this form of protection is usually at the mercy of ensuing storms, which wash them away. 
This part of Accra also has the Densu wetland, which is a Ramsar site as a wetland of international importance. It is habitat for sensitive endemic species and serves as a fly zone for migratory birds (Ahulu et al. 2006). The wetland is predicted to be inundated in the next 80 years when the barrier separating it from the sea is expected to breach (Appeaning-Addo et al. 2008).

According to Appeaning-Addo et al. (2008) the study area is considered to be extremely vulnerable due to the relatively low elevation and the presence of poorly consolidated sediment. Hence the increasing trend in shoreline erosion is expected to have severe repercussions. There is therefore a need to understand the cyclical shoreline-changing trend by determining the short-term rate of erosion in Glefe. This information will inform decision making concerning sustainable management of the coastal resources along the Glefe shoreline and effective management of disaster risk.

\section{Methodology}

A summary of the method adopted for this study is represented as a flow chart in Figure 3. A field survey on 15 February 2011 involved GPS data collection and a laboratory session. The field survey started with a reconnaissance survey through establishment of a control point, coordinating the $\mathrm{X}, \mathrm{Y}$ and $\mathrm{Z}$ components of the established control point into the Ghana national grid system, identification of a shoreline proxy (which in this case was the high-water line), and finally mapping of this shoreline proxy. The laboratory session involved obtaining an orthophoto and digitising the study area's historic shoreline from it. Also in the laboratory scripts were developed in MATLAB to analyse and overlay the obtained shorelines, and further compute the rate of change using the EPR method.

The mapping of the shoreline proxy was done by setting up a GPS receiver set over the base station and running the mounted rover on a monocycle along the identified shoreline proxy. Both the high- and low-water marks were mapped as well as other identified features such as berms and dunes. This survey method was chosen because it uses differential corrections with two GPS receivers employed, one at a known point. The corrected coordinates are accurate in the $1 \mathrm{~m}-5 \mathrm{~m}$ range. Also, the use of phase differential processing techniques produces centimetre-level position accuracy. Moreover, the combination of real-time kinematic and radiomodem technology produces the exact coordinates of the points that a rover receiver occupies (Huang et al. 2002).

Scripts for analysis and further processing of the raw data were written in MATLAB in the laboratory session. The historical shoreline position was digitised from a 2005 orthophoto map covering the study area in a geographic information system environment. The two shorelines were analysed by overlaying them in MATLAB and computing the average rates of change along transect lines at equal intervals along the shore.

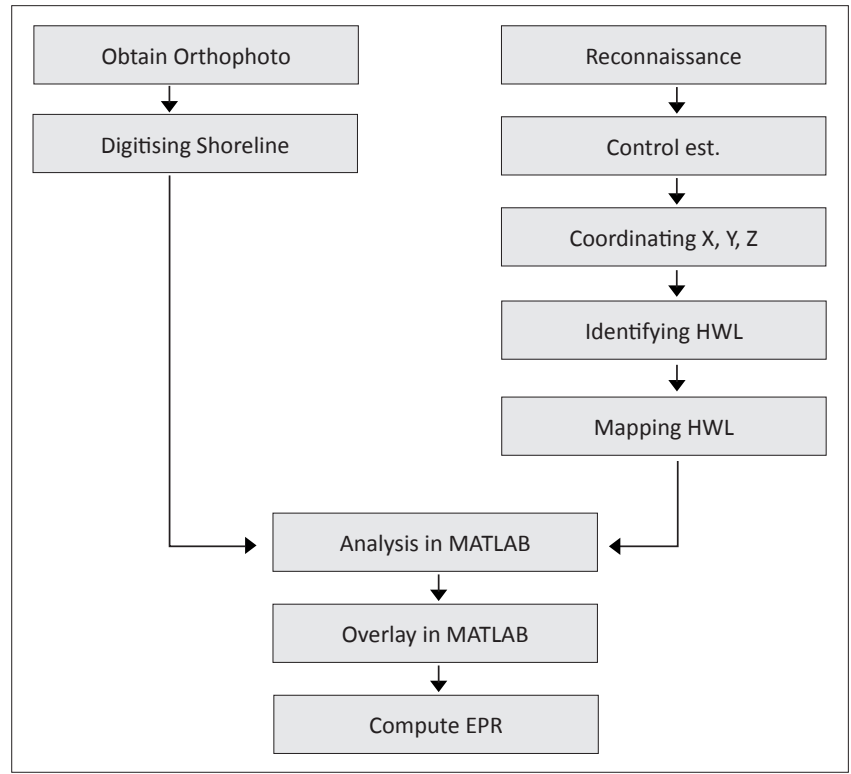

FIGURE 3: A flow chart of the processes employed in study $(\mathrm{HWL}=$ high water line).

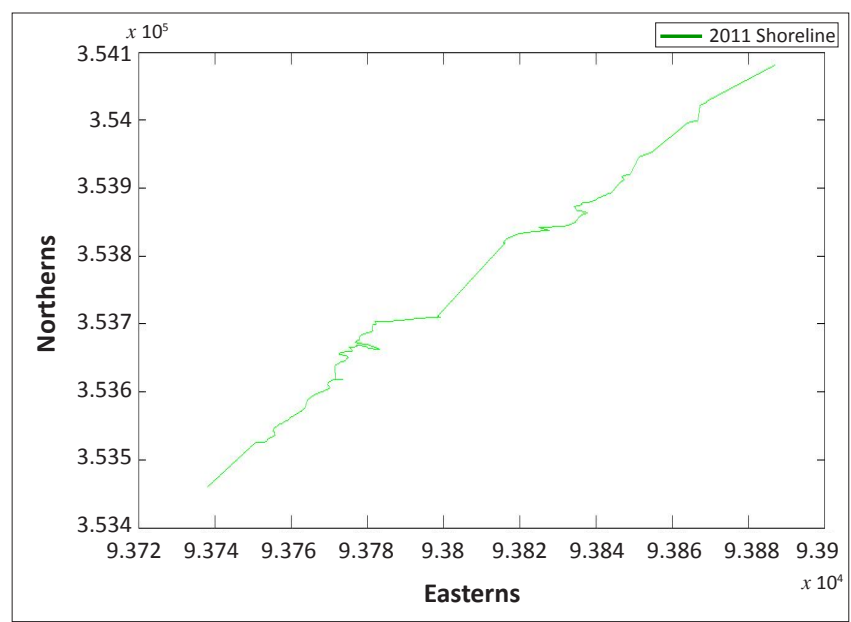

FIGURE 4: Plot of shoreline proxy (high water line) data from RTK-GPS survey.

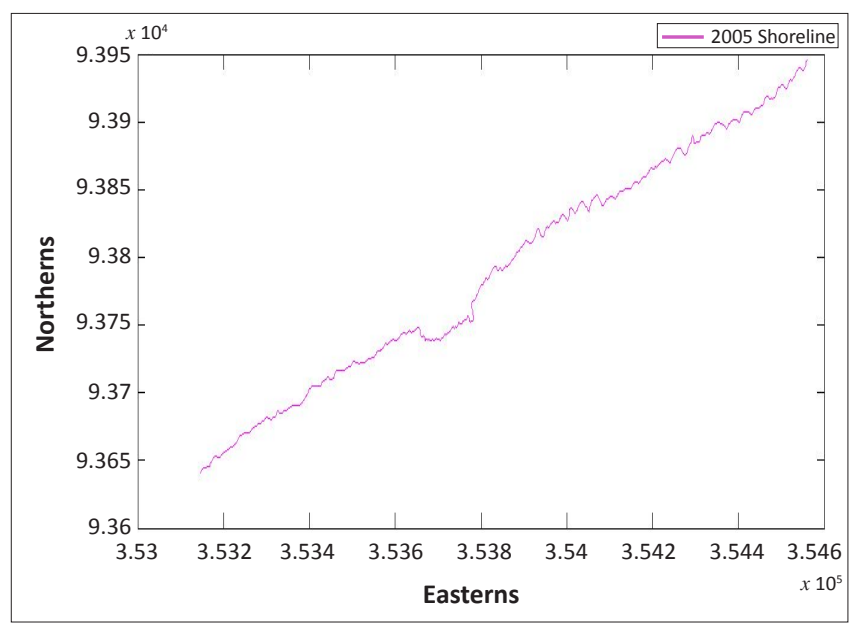

FIGURE 5: Plot of historical shoreline (high water line) obtained from the 2005 orthophoto. 


\section{Results}

The average rate of erosion at the study site obtained from 2005 to 2011 was $1.2 \mathrm{~m} / \mathrm{a} \pm 1.3 \mathrm{~m} / \mathrm{a}$. The following are the various results obtained during individual data analysis stages and calculation of the average erosion rate, all in the MATLAB environment. A plot of the RTK-GPS data (Figure 4) indicated that the shoreline is quite linear. A riprap installed at the Pambros pumping site is the only feature that presents a significant morphological difference, indicated by the L-shape in the middle of the plot, which seems to interfere with long shore transport. On the figure the seaward side of the beach is represented by the portion below the shoreline position and the landward side above the shoreline position.

The historical shoreline obtained from the orthophoto (see Figure 5), on the other hand, shows a shoreline with variations in morphology, indicated by the undulating shoreline position on the graph. This reveals that that the shoreline position in 2005 was more variant in terms of resistance to erosion.

The overlay of both shorelines in MATLAB (see Figure 6) showed how dynamic the shoreline has been during the past five years. The gap between the shorelines represents the distance over which the beach has eroded during the six-year period. High erosion is observed at the location with intervention (riprap). Furthermore, the eastern part of the beach also indicates significant variation in shoreline morphology, and thus wider gaps between the shorelines. The western part of the beach showed less variation over the study period.

Transect lines generated parallel to a baseline at $5 \mathrm{~m}$ intervals and crossing the shorelines were used to calculate erosion rates along the shore (see Figure 7). The net average of rates along each transect is the average rate of erosion for the Glefe beach.

Figure 8 shows the differences in rates of erosion along the beach. Each bar represents a $5 \mathrm{~m}$ block of the beach along which erosion was measured. The largest rate of erosion recorded occurred at the present riprap installation, which is indicated on the graph by the high bars (between bars 49-70). High bars on the eastern part of the graph are also an indication of higher erosion rates there.

\section{Discussion}

The average rate of erosion at Glefe for the short term was estimated to be about $1.2 \mathrm{~m} / \mathrm{a} \pm 1.3 \mathrm{~m} / \mathrm{a}$. This indicates a high erosion rate for the past six years. The significant historical rate threatens the coastal environment. This explains the increased destruction of coastal infrastructure (Campbell 2006) and displacement of the local inhabitants (Oteng-Ababio et al. 2011). Destruction of the beaches, which serve as the natural fish landing sites, are collapsing the local fishing industry and increasing problems associated with unemployment.

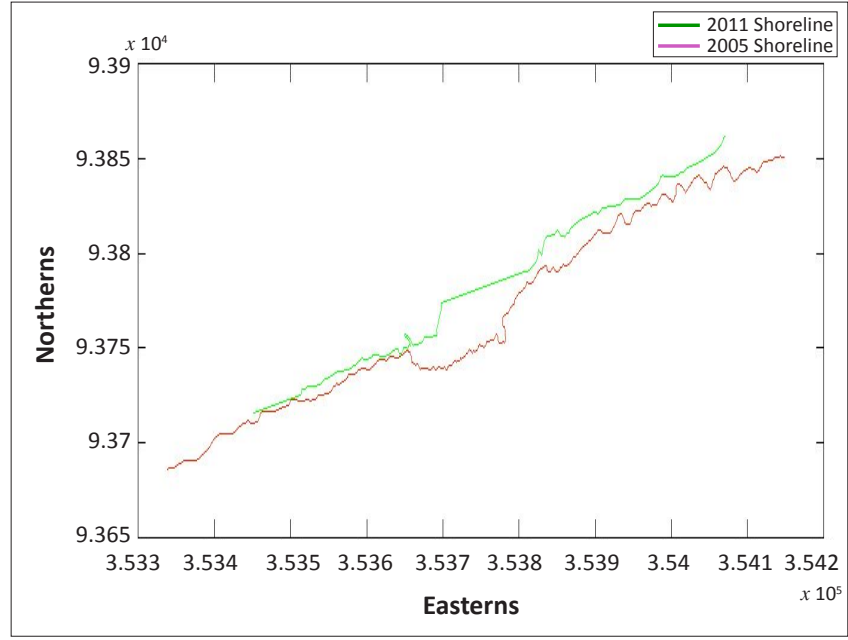

FIGURE 6: Overlay of digitised and mapped shorelines in MATLAB.

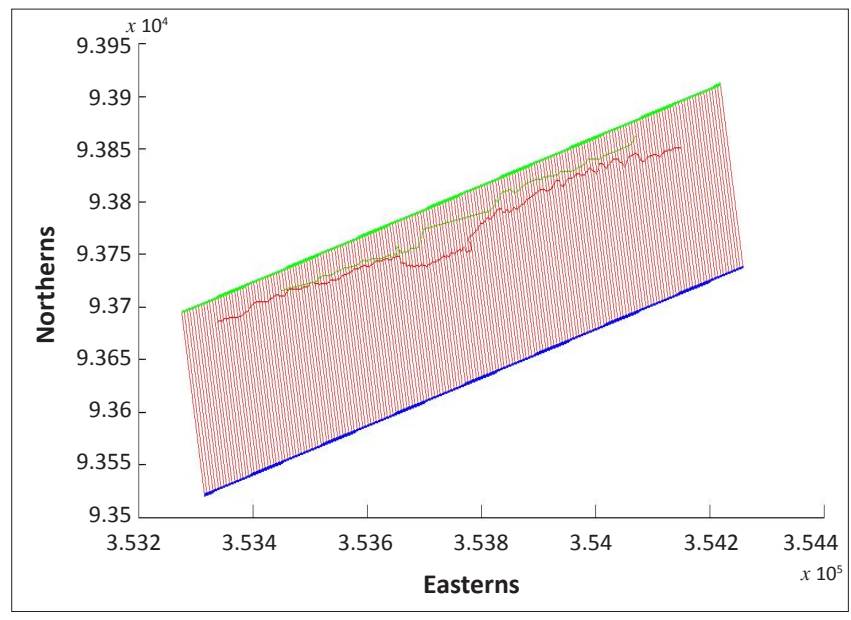

FIGURE 7: Orthogonal lines projected from a baseline for rate of change computation using the EPR method.

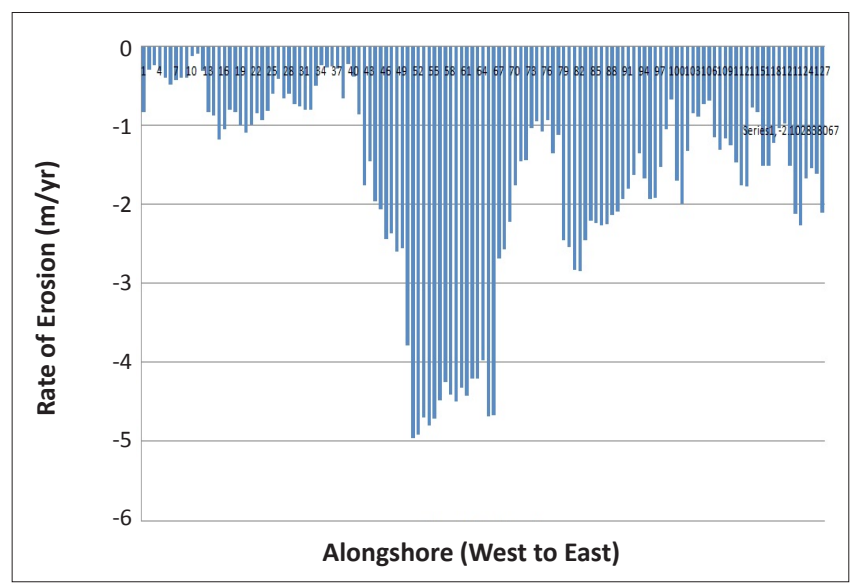

FIGURE 8: Erosion rates alongshore using the EPR method.

The observed trend is expected to continue with increasing sea level, which will impact the Densu wetlands. According to Appeaning-Addo (2009b), the Densu wetlands is the second most important site for the rare stern Dougallii, and flooding of this ecological site will affect about 35000 waterfowl and endanger the habitats of migratory birds. Flooding of the saltpans of the salt industry will further swell the unemployment problem that prevails in the study area. 
The estimated uncertainty rate is larger than the rate obtained, and this may be due to discrepancies that occurred during the field survey and other errors obtained from the processed orthophoto. During the field survey shoreline data could not be obtained for the Pambros pumping site due to inaccessibility of the area, and hence the data set for this area was generated by the MATLAB software. However, data for this area representing the 2005 shoreline position were obtainable using aerial photography. Due to these differences that area appeared to have huge erosion rates, which could be an outlier. Moreover, high-magnitude events such as storm surges may have occurred during the period of study. Although the period of recurrence is not known, this may have contributed to the huge error obtained.

Aside from sea level rise and allied increases in wave activities that are known to be causes of erosion along most of Ghana's beaches (Appeaning-Addo et al. 2008), the following activities which interfere with beach processes may be responsible for the exacerbated erosion at Glefe. Sand mining (see Figure 9) is a prevalent activity along most Ghanaian shores (Wiafe et al. 2010; Appeaning-Addo 2009b), and is also true for the Glefe beach. Factors leading to excessive sand mining there are mainly construction activities such as the building of new homes to accommodate the increasing population. According to Wiafe et al. (2010), beach sand mining activities have been banned and stringent regulations have been put in place to ensure compliance at the district level. However, the absence of enforcement encourages those from other communities to join in this activity.

Also, observations at the beach indicated that Pambros Salt Production Limited draws a huge amount of sea water directly from the surf zone for their production. However, in the surf zone there is suspension of beach sediment due to wave breaking (Davis \& Fitzgerald 2010); hence water taken up from here is not without sediment. This leads to siltation of their reservoir within a few months. Dredged spoil from here is placed on the banks, from where it is collected by local people for various activities. This leads to a loss of sediment by the beach which is very significant.

Furthermore, beaches around the world have become the pinnacle of most lucrative and luxurious establishments (Cunningham \& Cunningham 2006). Glefe and its immediate environs are no exception. This coastal urbanisation, which is a serious threat to beach ecosystems at Glefe, has led to the damage or degradation of most sand dunes that serve as the 'bank accounts' of the beach. Natural depletion of prograded beaches is also a probable cause of the exacerbated erosion experienced at Glefe (Glefe, like most other West African beaches, is prograded [Schwartz 2005]). These beaches are thus sensitive to any long-term changes in wave energy resulting from sea-level rise. These activities deprive the beach of sediment needed for replenishment of that lost to long-shore transport. This further aggravates the process of erosion occurring at Glefe.

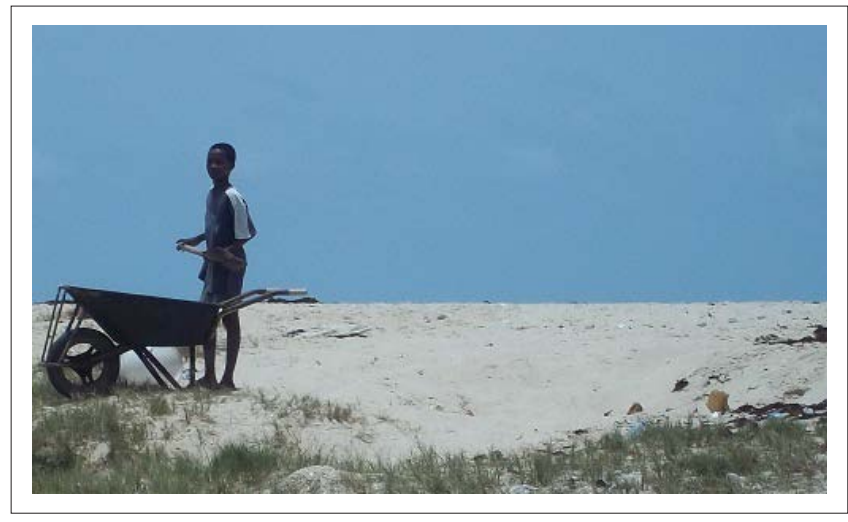

Source: Photo taken by Kwadwo Amoani, Kwasi Appeaning-Addo, Wahab Laryea

FIGURE 9: Excessive sand mining at Glefe beach is contributing to severe erosion.

The study area falls within the central geomorphic region of Ghana which is characterised by rocky outcrops (Armah 2005). Some of these rocky outcrops consist of materials that make them slightly insoluble and hence to some degree resistant to erosion by small wave action. Consequently these points remain intact despite erosion at nearby beaches, and their sediment supply is reduced (Davis \& Fitzgerald 2010). Also, several studies have established the fact that the longshore drift along the West African coast is eastward. The combined effect of these two factors leads to exacerbated erosion downdrift (at Glefe), since the beach may not have received or have enough sediment supply to release to long-shore drift in any case of the greater storminess now prevalent due to increased sea levels.

The effects of erosion at Glefe vary significantly. The major effect is the increased economic loss incurred by inhabitants and private entity owners. Erosion results in rapid loss of property, especially those sited on the back-beach, such as homes and Pambros pumping plant. Another consequence of the erosion is the rapid loss of the Densu wetland, especially the Gyatakpo or Bugbe lagoon, to reclamation. Residents who lose their homes to erosion reclaim land by infilling of the lagoon and associated wetlands, leading to its gradual loss.

All of these factors exacerbate the hazard risk, especially on the eastern part of the beach where erosion is most severe and the population is relatively high. Thus erosion poses an eminent and imminent hazard to livelihood, infrastructure and the general environment in the study area.

There is the urgent need for concerned parties, with the inhabitants as key agents, to put in place stringent measures to manage the current situation and reduce worsening thereof.

\section{Conclusion}

The short-term evolution trend of the shoreline in Accra has been established. Possible causes and effects of erosion were determined, which include economic losses accompanied by loss of livelihood and loss of the Gyatakpo or Bugbe lagoon. 
The study determined that the average rate of erosion between 2006 and 2011 was about $1.2 \mathrm{~m} / \mathrm{a} \pm 1.3 \mathrm{~m} / \mathrm{a}$, which is relatively high. If the shoreline continues to erode at this rate, the future consequences may be devastating, and this increases the state of vulnerability of the study area. There is therefore the need to initiate programmes involving the local inhabitants to adopt sustainable measures to manage the risk associated with coastal erosion.

It emerged from the study that continued beach sand mining practices have the tendency to exacerbate the erosion situation. Efforts should be made to enforce the ban on sand mining by the various stakeholders to reduce the risk associated with this activity.

\section{Acknowledgements Competing interest}

The authors declare that they have no financial or personal relationship(s) which may have inappropriately influenced them in writing this article.

\section{Authors' contributions}

A.K.Y. (University of Ghana) was the main writer of the manuscript, performed data analysis and the field survey, A.K. (University of Ghana) was the mentor and supervisor of the project as well as part writer of the manuscript and L.W.S (University of Ghana) wrote the Matlab algorithm for the data analysis and rate computation and was also part of the field survey.

\section{References}

Ahulu, M.A., Nunoo, F.K.E. \& Owusu, E.H., 2006, 'Food preferences of the common tern, Sterna hirundo (Linnaeus, 1758) at the Densu Floodplains, Accra', West African Journal of Applied Ecology 9, 141-148.

Al-Tahir, R. \& Ali, A., 2004, 'Assessing Land Cover Changes in the Coastal Zoning Aerial Photography', Surveying and Land Information Science 64(2), 107-112.

Appeaning-Addo, K., 2009a, 'Detection of coastal erosion hotspots in Accra - Ghana', Journal of Sustainable Development in Africa 11(4), 253-265.

Appeaning-Addo, K., 2009b, Detection, measurement and prediction of shoreline change in Accra, Ghana, Lambert Academic Publishing, Saarbrücken.

Appeaning-Addo, K., Walkden, M. \& Mills, J.P., 2008, 'Detection, measurement and prediction of shoreline recession in Accra, Ghana', Journal of Photogrammetry \& Remote Sensing 63(5), 543-558.

Armah, A.K., Biney C, Dahl S.O. \& Povlsen, E., 2004, Environmental Sensitivity Map of the Coastal Areas of Ghana Volume II - Coastal Environment, UNOPS/UNDP, Accra, p. 80, viewed 01 September 2011, from http://www.kosmosenergy.com/ eias/Jubilee_Field_EIA_References_25Nov09.pdf

Armah, A.K., 2005, 'The Coastal Zone Of Ghana: Vulnerability and Adaptation Assessment to Climate Change', paper presented at the Vulnerability and Adaptation Assessment Training Workshop, Maputo, Mozambique, 18-22 May, viewed 01 September 2011, from http://www.ug.edu.gh/fos/vbrp/climate/2005_ Climate Change Adaptation Assessment_Ghana_Armah.pdf

Bellomo, D., Pajak, M.J. \& Sparks, M.J., 1999, 'Coastal Flood Hazards and the National Flood Insurance Program', Journal of Coastal Research Special Issue (28), 21-26.
Bird, E.C.F., 2008, Coastal geomorphology: An introduction, 2nd edn., Wiley, Chichester.

Campbell, M.O., 2006, 'The sustainability of coconut palm Cocos Nucifera Linnaeus 1753 in Coastal Ghana', Journal of Coastal Research 22(5), 1118-1124.

Coastal Engineering Research Center, 1984, Shore Protection manual, vols. 1 \& 2, US Army Coastal Engineering Research Center, Washington, D.C.

Cunningham, P.W. \& Cunningham, M.A., 2006, Principles of environmental science: Inquiry and applications, 3rd edn., McGraw-Hill, Boston, IL.

Dahm, J., 2000, 'Natural Character: Concept Development in New Zealand Planning Law and Policy', Environment Waikato, Hamilton.

Davis, R.A. \& Fitzgerald, D.M. 2010, Beaches and Coasts, Wiley-Blackwell, Oxford.

De-Graft, S.J., 2011, 'Environmental Issues', radio broadcast, Joy FM, 08 April.

Douglas, B.C. \& Crowell, M. 2000, Long-term shoreline position prediction and error propagation', Journal of Coastal Research 16(1), 145-152.

Douglas, B.C., Crowell, M., \& Leatherman, S.P., 1998, 'Considerations for shoreline position prediction', Journal of Coastal Research 14(3), 1025-1033.

Hanson, H., Gravens, M.B. \& Kraus, N.C., 1988, 'Prototype applications of a generalized shoreline change numerical model', in B.L. Edge (ed.), pp. 1265-1279. Proceedings of the 21st International Conference on Coastal Engineering, Costa Del Sol, Malaga, Spain.

Huang, J.D., Jackson, D.W.T. \& Cooper, J.A.G., 2002, 'Morphological monitoring of a high energy beach system using GPS and total station techniques, Runkerry, Co. Antrim, Northern Ireland', Journal of Coastal Research Special Issue (36), 390-398.

Leatherman, S.P., 2001, 'Social and economic costs of sea level rise', in B.C. Douglas, M.S. Kearney \& S.P. Leatherman (eds.), pp. 181-224, Sea level rise history and consequences, Academic Press, San Diego, CA.

Ly, C.K., 1980, 'The role of the Akosombo Dam on the Volta River in causing erosion in Central and Eastern Ghana (West Africa)', Marine Geology 37, 323-332. http:// dx.doi.org/10.1016/0025-3227(80)90108-5

Morton, R.A. \& Speed, F.M., 1998, 'Evaluation of shorelines and legal boundaries controlled by water levels on sandy beaches', Journal of Coastal Research 14(4), 1373-1384.

Morton, R.A., Leach, M.P., Paine, J.G. \& Cardoza, M.A., 1993, 'Monitoring beach changes using GPS surveying techniques', Journal of Coastal Research 9(3), $702-720$.

Nail, G.G., Addo, M.J.A. \& Wellens-Mensah, J., 1993, Coastal erosion points in Ghana and their protection: Report of the national workshop on climate climate change and in its impact on water, oceans, fisheries and coastal zones - Accra: Ghana National Committee for the International Hydrological Programme, pp. 189-202.

National Research Council, 1990, Managing Coastal Erosion, National Academy Press, Washington, D.C.

Oppong, D. \& Quashie, A., 2006,'Ghanaian Solar Saltworks: Promoting and protecting the ecology', Paper presented at the 1st International Conference on the Ecological Importance of Solar Saltworks (CEISSA 06), Santorini Island, Greece, 20-22 October 2006, viewed 01 September 2011, from http://www.srcosmos.gr/ srcosmos/showpub.aspx?aa $=7868$

Oteng-Ababio M., Owusu K. \& Appeaning-Addo, K., 2011, 'The vulnerable state of the Ghana coast: The case of Faana-Bortianor', Jàmbá: Journal of Disaster Risk Studies 3(2), 429-442.

Pajak, M.J. \& Leatherman, S., 2002, 'The high water line as shoreline indicator', Journal of Coastal Research 18(2), 329-337.

Smith, A.W.S. \& Jackson, L.A., 1992, 'The variability in width of the visible beach', Shore and Beach 60(2), 7-14.

Schwartz, M. (ed.), 2005, Encyclopedia of Coastal Science, Dordrecht, Springer, p. 1211.

Romine, B.M., Fletcher, C.H., Frazer, L.N., Genz, A.S., Barbee, M.M. \& Lim, S.C., 2009, 'Historical shoreline change, Southeast Oahu, Hawaii; applying polynomial models to calculate shoreline change rates', Journal of Coastal Research 25(6), 1236-1253. http://dx.doi.org/10.2112/08-1070.1

United Nations Environment Programme, 1999, 'Overview of land-based sources of and activities affecting the marine, coastal and associated freshwater environment in the west and central African region (UNEP Regional Seas Reports and Studies No. 171)', UNEP/GPA Co-ordination Office, The Hague, viewed 01 September 2011, from http://www.oceandocs.net/bitstream/1834/312/1/UNEP171.pdf

Wiafe, G., Appeaning-Addo, K., Ababio, K., Agyekum, K., Ashton, A., Hapke, C., et al., 2010, 'Coastal Processes Research in Ghana', paper presented at Ocean Science Conference, Oregon Convention Center Portland, Oregon, United States of America, 22-26 February. 